\title{
The Endemic Crisis of Federalism in Pakistan
}

\section{Raza Ahmad*}

\begin{abstract}
This paper looks at the issue of federalism in Pakistan. It begins with an analysis of the conceptual paradigms of federalism and goes on to examine the history of federalism in Pakistan. The paper goes on to discuss the reasons for the failure to develop an organic federal covenant as well as discuss how the $7^{\text {th }}$ National Finance Commission (NFC) Award and the $18^{\text {th }}$ Amendment may be indicative of a paradigm shift. The paper concludes by presenting the way forward for federalism in Pakistan.
\end{abstract}

Keywords: Federalism, governance, Pakistan.

JEL Classification: H77, O2.

\section{Introduction}

This paper will examine the history of Pakistan's experiments with systems of state governance, with a view to understanding the dynamics of Pakistan's various federal arrangements and their impact over time. In doing so, this paper will argue that Pakistan has failed to establish an effective federal covenant between its constituent units, despite some incremental movements toward regional autonomy and devolution. It will further argue that, in an attempt to shift the focus of the analysis toward the agency of societal forces, the failure to create a workable national covenant has led to what may be called the syndrome of a 'failing society'. This assertion will entail an analysis of contemporary political attempts to rectify the dynamics between federating units, for charting the potential course of Pakistan's future federal arrangements.

Before one can embark on the task of tracing Pakistan's federal trajectory, however, it is necessary to theoretically identify, locate, and explicate federalism in order to comprehend its significance in the context of the Pakistani state.

\footnotetext{
* Raza Ahmad is a policy adviser and researcher based in Lahore. He has worked with the Asian Development Bank, United Nations and the Government of Pakistan.
} 


\section{Federalism in Conceptual Paradigms}

\section{A Working Definition of Federalism}

Ronald Watts (1998) defines a federation as

a compound polity combining constituent units and a general government, each possessing powers delegated to it by the people through a constitution, each empowered to deal directly with the citizens in the exercise of a significant portion of its legislative, administrative, and taxing powers, and each directly elected by its citizens (Watts, 1998, p. 121).

As a normative concept, federalism is the advocacy of a pragmatic balancing of citizen preferences for (a) joint action for certain purposes and (b) self-government of the constituent units for other purposes.

\section{Federalism and Social Capital}

Jason Mazzone (2001) argues that federalism promotes the kinds of social relationships that allow citizens to overcome collective action barriers and get things done. That is, federalism has value because it promotes social capital or 'features of social organization such as trust, norms, and networks that can improve the efficiency of society by facilitating coordinated action' (Mazzone, 2001, p. 27).

An important benefit of dividing authority between the national government and sub-national units is that such division increases the points of political power over which citizens can exert influence in order to achieve their goals. Rather than facing a single governing entity under a federal system of government, citizen groups (whether ideological, ethnic, civic, or otherwise) can influence political outcomes by directing their resources toward local, state, and national levels. A political environment in which there are multiple sites for influence promotes the emergence of social capital because such an environment is conducive to a large number of interest groups in which citizens actively participate. Thus, federalism provides opportunities for smaller groups of the citizenry to organize and pursue their goals in a variety of settings, rather than relegating vast numbers of citizens to passive roles in a large national advocacy group which pursues its members' interests in the center. In other words, when political power is divided, it is more difficult for any single interest group to dominate. Divided political power, therefore, increases opportunities for engagement in government by additional groups of citizens, thereby enhancing social capital (Mazzone, 2001, p. 42). 
This theory is borne out by the cases of various multi-cultural and multi-ethnic federations, such as the United States, Canada and our neighbors to the East. It is especially relevant to the case of Pakistan, where multiple societal cleavages have led to the 'failed society' syndrome.

\section{Federalism as a Covenant}

The etymological roots of federalism can be traced back to the Latin 'foedus' or covenant. The word was initially used to describe cooperative, contractual agreements between states, usually for defense purposes. A covenant implied mutuality, with each party fulfilling certain obligations toward the others (Rodden, 2005, p. 489). From such an understanding, it follows that a situation where the central government utilizes local governments as instruments for achieving its ends simply by virtue of administrative fiat cannot be viewed as a contractual or federal relationship. Federalism, by its very definition, implies that for some subset of the central government's decisions or activities, it is necessary to obtain the consent or active cooperation of the sub-national units (Rodden, 2005, p. 489).

To make sense of the concept, however, it is important to understand how and why federal contracts are made in the first place. Federalism, both in terms of definition and operation, is inextricably tied to the historical circumstances in which the contract is formed and applied. As mentioned earlier, many federations, particularly those in Europe, arose out of a bargain aimed at achieving military defense against a common enemy (with the subsequent addition of other collective goods into the contract, such as free trade and currency) (Rodden, 2005, p. 489). However, for the purpose of understanding the situation as it exists in Pakistan, it is important to bear in mind that, in many postcolonial states, the modern federal bargain did arise from a mutual need for defense or otherwise, but rather out of the vagaries of colonial policies and their sociopolitical ramifications. It is in this historical context that we must view the case of Pakistan, where federalism has struggled to take root even, more than 60 years after independence.

\section{The Overdeveloped State Hypothesis}

An instrument of analysis that may be employed to better grasp Pakistan's federal dilemmas is that of Hamza Alavi's 'Overdeveloped State'. Alavi argued that (a) the original base of the state apparatus inherited by a postcolonial society lay in the metropole (i.e., the colonizing country) and, (b) its task was to subordinate all the indigenous classes or groups in the colony (or ex-colony) and hence it was 'overdeveloped' in relation to the excolonial society. The state also inherited, according to Alavi, a strong 
military-administrative apparatus and directly appropriated a large part of the national economic surplus. Alavi held that postcolonial states were characterized by 'centrality', embodied in the power of the state bureaucracy (Leys, 1976, pp. 39-40). The overdeveloped state thesis is vital in understanding Pakistan's failed experiments in federalism, as it is emblematic of the antagonistic, colonial relationships that have endured between the smaller provinces and the powerful center.

\section{History of Federalism in Pakistan}

\section{Pre-Partition: The Mughal Era and the British Empire}

In some senses, federalism has long been rooted in the statecraft of the subcontinent. Devices of territorial autonomy were used as a means of managing diversity and as methods of government in the time of the Mughals, though it is arguable as to what extent they were effective. The British also understood the administrative necessity of federalism as a tool to perpetuate their rule over the subcontinent, with a gradual delegation of power and responsibilities over time to the states and provinces of India from 1919 onwards (Adeney, 2007, p. 121). With gradual increments, the British experiment with federalism culminated in the Government of India Act of 1935, at a time when tensions between the colonizer and the colonized had transformed into a dialectic between British constitutional experiments and Indian reactions to them. The Act was a document of partial self-rule for India, a constitutional outline that appropriated the language and the institutions of the liberal state but which emphasized British parliamentary control, in part by the pervasive possibility, and use, of emergency powers (Newberg, 1995, pp. 17-19).

\section{The Wrong-Footed Beginning and the Military-Bureaucracy Nexus}

The Lahore Resolution of 1940, while resolute in its commitment to provincial sovereignty and weak central rule, also represented a contract between the Muslim League (1argely representative of the Muslims in Muslim-minority provinces) and the landed elite in the areas that were to constitute Pakistan. In a sense, this was the death-knell for any meaningful federalism in Pakistan; the Muslim League was now wedded to landed, communal interests along with the incorporation of a deep-rooted suspicion within the Muslim League ranks for multi-ethnic pluralism, in the quest for the articulation of a representative Muslim unity. According to Paula Newberg (1995), contemporary Pakistan's continuing difficulties to reach concord on issues of representation and democracy are derived in some measure from this early decision to view provincial, economic, and political 
rights through the lens of provincial and feudal interests (Newberg, 1995, p. 19). This was compounded by the centralized administrative structure laid out in the Act of 1935, which was to form the basis for much of pre- and post-independence Pakistani constitutional politics as well as the constitutional experiments of 1956 and 1962.

The challenges to the articulation of a federal structure posed by the multi-ethnic character of the newly-created Pakistan were brought to the fore by the initial wrangling over the composition of the Houses of Parliament. In 1951, the Basic Principles Committee Report set out a draft of a constitution based on the principles of equal representation in the upper house, but left the composition of the lower house unclear. The Bengalis deemed this to be unacceptable, being the majority ethnicity of independent Pakistan. Bengali demands that they have a majority in both houses of parliament were equally unacceptable to the provinces of the western wing, which feared a loss in their economic and political clout to the eastern wing in such a scenario (Adeney, 2007, pp. 104-105).

Drafted by the bureaucrat Chaudhry Muhammad Ali, the first (hopelessly delayed) Constitution of 1956, 'resolved' this problem by creating parity between the two wings of Pakistan, with 150 seats for each in a unicameral national legislature. Hence, an unstable bipolar federation, the likes of which have been empirically observed to be much more likely to fail (Adeney, 2007, p. 172) was formed. Unlike the norm in multi-ethnic federations, the boundaries of federated units were not revised to accommodate territorially concentrated linguistic communities. Coupled with this was the refusal to recognize 'regional languages', barring provinces from adopting languages of their choice (Adeney, 2007, pp. 106-107). Thus, from the perspective of federalism that has been theoretically utilized in this paper, Pakistan's early constitutional experiments were representative of a breach in the federal covenant and a failure in consensus-building. However, even before elections could be held under this centralized constitutional arrangement, the bureaucratic and military arms of the state colluded to usurp power in 1958 and create an even more centralized political and administrative structure, embodied in the wholly executive-oriented Constitution of 1962.

The second constitution, again framed by a representative of the military-bureaucratic oligarchy, did not refer to the federal system in its description of the name of the state. The constitution completely excluded the provincial list of subjects and created a central list of 49 items, along with a concurrent list. Thus, through these moves, the concentration of power was retained for the President and a unicameral legislature. The provincial governments were to be headed by President-appointed governors 
enjoying enormous power and leverage (Naseer, 2007). The centralized state organization of the 1956 and 1962 constitutions, rife with Punjabi domination, an overdeveloped, all-powerful military-bureaucratic oligarchy and insensitivity to ethnic differences resulted in the tragic breakup of the country in 1971 .

The 1973 constitution, however, marked a break in this uninhibited flow of power toward certain interest groups, in that it created a representative parliamentary system offering certain significant concessions to provinces (1anguage, cultural, principal decentralization). However, the preponderance of one province (Punjab) over the rest remained due to its overwhelming representative majority in the Lower House, among other provisions (such as federal and concurrent lists, to be discussed in next section). Moreover, the provincial list continued to be absent in the 1973 constitution, with a federal list of 59 subjects and a concurrent list of 47 subjects. However, implementation of the pro-participatory clauses emerged as weak, with institutions such as the Council of Common Interests and the National Finance Commission-created to resolve inter-provincial disputes and provide a platform for democratic discourse-functioning without potency and eventually falling into dormancy. Executive authority continued to retain primacy in most matters (Naseer, 2007).

Tables-1 to 3 below represent indicators illustrating some of the regional disparities that have arisen as a result of the lack of a meaningful and equitable federal system.

Table-1: Population below the poverty line

\begin{tabular}{lccccc}
\hline Province & Overall & $\begin{array}{c}\text { Provincial } \\
\text { Capital }\end{array}$ & $\begin{array}{c}\text { Large } \\
\text { Cities }\end{array}$ & $\begin{array}{c}\text { Small } \\
\text { Cities }\end{array}$ & $\begin{array}{c}\text { Rural } \\
\text { Areas }\end{array}$ \\
\hline Punjab & 26 & 19 & 21 & 42 & 24 \\
Sindh & 31 & 11 & 20 & 38 & 38 \\
KP & 29 & 28 & 0 & 41 & 28 \\
Balochistan & 48 & 16 & 0 & 41 & 52 \\
\hline
\end{tabular}


Table-2: Average growth rate of per capita income

\begin{tabular}{lcccc}
\hline Year & Punjab & Sindh & $\begin{array}{c}\text { Khyber- } \\
\text { Pakhtunkhwa }\end{array}$ & Balochistan \\
\hline $1972-1977$ & 2.09 & 0.43 & 1.04 & -0.26 \\
$1977-1985$ & 3.62 & 4.58 & 4.27 & 0.70 \\
$1985-1990$ & 2.27 & 2.64 & 4.27 & 3.44 \\
$1990-2000$ & 1.99 & 1.71 & 1.64 & 1.53 \\
$1972-2000$ & 2.58 & 2.54 & 2.89 & 0.49 \\
\hline
\end{tabular}

Table-3: Human Development Index

\begin{tabular}{lcc}
\hline Area & HDI & Ranking \\
\hline Sindh Urban & 0.659 & 1 \\
Punjab Urban & 0.657 & 2 \\
KP Urban & 0.627 & 3 \\
Balochistan Urban & 0.591 & 4 \\
Punjab Rural & 0.517 & 5 \\
KP Rural & 0.489 & 6 \\
Balochistan Rural & 0.486 & 7 \\
Sindh Rural & 0.456 & 8 \\
\hline
\end{tabular}

\section{Beyond Federalism: Pakistan's Withering Social Cohesion}

Due to the lack of success in forming an organic covenant, social cohesion has been failing and exclusion marks the contours of Pakistani society. Inter-provincial and regional disparities have been exacerbated over the years, with clear distinctions emerging between the urban cores and rural peripheries. Social exclusion has increased on multiple levels in the country, be it on the basis of class, biraderi (kin), caste, ethnicity, hereditary occupational grouping, land ownership, or gender. The resultant limited opportunities for marginalized groups have prevented the exercise of human rights and participation in the process of governance. However, in accounting for this rampant acceleration in social exclusion, there has been a great deal of literature emphasizing the failure of the state in Pakistan. 
Stephen P. Cohen (2002), Rodney W. Jones (2001), L. P. Goodson (2001), and M. Ignatieff (2002) are some who have studied the concept of state failure in Pakistan and its experience in the modern $20^{\text {th }}$ century.

This paper attempts to present an alternative hypothesis which is cognizant of the symbiotic relationship between state and society, and takes into account the highly evident fractures in social cohesion in Pakistan, the understanding of which can be analyzed-and developed-using readily available facts, data, and interpretations of prevailing trends and sociopolitical phenomena in this part of South Asia. Pakistan's failure to develop an organic federal covenant may have led to what may be called a 'failing society', based on a number of interrelated variables which are detailed below.

\section{Political and Social Exclusion}

Access to political and economic power remains overwhelmingly the prerogative of the urban upper-middle classes of the larger provinces. Class, ethnicity, and religion also continue to serve as instruments of marginalization, evidenced partly by the depleted economic strength of religious and ethnic minorities, as well as by the lower-ranked hereditary occupational groups.

\section{Social Legitimacy of Corruption}

Pakistan has consistently ranked poorly on corruption indexes (currently $139 / 180$ on the TI index) without any significant societal resistance or overt backlashes. This phenomenon has been belied multiple times by the its rampant acceptance as a social norm, illustrated by on-the-record statements by lawmakers which have been in favor of corruption and corrupt practices; one legislator from the largest party in the parliament even claimed on national television that since everyone else who has governed Pakistan has been corrupt, it is his and his party's 'right' to partake in corruption. This disease, which is often couched in concepts of 'rent-seeking behavior', has gradually penetrated Pakistani society. Malfeasance, 'cutting corners' and the utilization of patron-client relationships-or creating them anew-has become politically and economically pervasive, and instrumentally entrenched in the nation's psyche.

However, there appears to be an emerging streak in Pakistani thought which has the potential of serving as a harbinger to future, overt resistance to corrupt practices in the country, especially by those whose location in Pakistani society makes them unable to benefit from these activities. This is manifest in the findings of Pew, IRIS and Gallup surveys, which show Pakistanis as being increasingly concerned about prevalent corruption levels. 


\section{Breakdown of Traditional Systems of Social Organization}

Pakistan is a country that has proceeded into modernity and the $21^{\text {st }}$ century while still retaining some of its traditional and out-dated conflictresolution mechanisms, especially illustrated by the culture of the dispensation of 'speedy justice' and 'enforcement of social norms'. Recent years have seen the breakdown of such systems that have not weathered well the onslaught of modernity, and they have increasingly become less effective in terms of dispensing credible justice or mediating between the state and rural citizenry.

\section{Religious Militancy and Intolerance}

Religious militancy has grown immensely in Pakistan in recent years. In 2009 alone, 2,586 terrorist, insurgent, and sectarian-related incidents were reported that killed 3,021 people and injured 7,334 (a 48\% increase over the previous year). ${ }^{1}$ Militant outfits in Pakistan are taking hold over the struggle for an ideology, which was convoluted in its adolescence during the Zia era, and due to the political and military expediency of Pakistan and its allies. The Tehrik-e-Taliban Pakistan (TTP), Lashkar-e-Jhangvi, Lashkar-eTaiba (LeT), Sipah-e-Sahaba and other militant and sectarian groups have targeted military and civilian targets at will, while finding sympathizers in not only the tribal areas of Khyber-Pukhtunkhwa, but moreover, in the urban centers of Punjab and Sindh as well. What is conspicuous in these occurrences is the muted or at times apologetic reaction of individuals who find their identity located outside of the target groups.

Additionally, the suffusion of conservative ideals and the creation of "middle-class Islamism" through organizations such as the A1-Huda have reduced the tolerance level of society to diversity, in a country for which survival hinges on pluralism. Across the board, sectarian violence and intolerance of other faiths, minorities as well as fellow sects has increased. In tandem, attacks on minority groups, including Christians, Sikhs and Ahmadis have also accelerated without significant societal outcry, demonstrating the growing tolerance of openly xenophobic violence in Pakistan.

\section{Unequal Benefits of Citizenship}

Few benefits of citizenship accrue to the residents of the Federally Administered Tribal Areas (FATA), Provincially Administered Tribal Areas (PATA), Azad Jammu and Kashmir (AJK), Gilgit-Baltistan (GB), Balochistan, parts of south Punjab, and areas where non-Muslim communities have settled.

1 Source: http://www.dawn.com/wps/wcm/connect/dawn-content-library/dawn/thenewspaper/front-page/16-over-12,800-militants-caught-in-2009-110-hs-06 
Such postcolonial subjects continue to maintain only the most fragile association with formal citizenship, and interact with a state that sustains itself by violating its own regulations. This is apparent, in the case of the remote citizenry, brought out by the near-complete unavailability of basic state services in areas like FATA, GB and other such areas. Prominent is the perpetuation of violence, together with discriminatory legislation against religious minority groups (such as the $2^{\text {nd }}$ Amendment and the blasphemy laws that are consistently abused and exploited as an instrument of marginalization).

\section{Exclusionary and Fragmented, Localized Identities}

Three quarters of the youth in Pakistan see themselves as Muslims first and Pakistanis second, compared to just $14 \%$ who see themselves as primarily citizens of Pakistan (Pew Research). With the failure of the state to serve as an adequate patron, mediator, and service provider, identities are increasingly tied to local and tangible elements of psychological security and social prosperity, rather than being bound to the federal polity which has historically appeared distant and apathetic. Various sectarian, ethnic, and caste institutions and organizations command the loyalty, respect, and even the lives of Pakistanis more than the Pakistani state, or the Pakistani identity, does.

\section{Alienation from the 'Political Society'}

The poor engage with the local state and intermediaries through a process known as 'governmentality', and a general disconnect between the arena of political debate and the corridor of actual executive power, has made the average citizen, voter or constituent feel alienated from the arenas of political action and empowerment.

The above-mentioned qualitative indicators can serve as an adequate illustration of the societal failure that has been wrought by an inadequate and unequal federal contract in Pakistan. Given the bleak situation, a reimagining of the power and resource calculus at multiple levels has become vital to the existential maintenance of Pakistani state and society.

\section{A Silver Lining: The New Wave of Political Consensus}

Recent events in the political sphere, however, may be indicative of important changes in the rules of the game. Of these, the first significant step is one that seeks to correct the distributive inequalities between Pakistan's provinces: the enactment of the $7^{\text {th }}$ National Finance Commission (NFC) Award. With the PPP government appearing set to potentially run its course, the coalition has done well to establish some semblance of democracy in the country, an important, corrective consequence of which has been the $18^{\text {th }}$ 
Amendment. Issues faced by the democratic government have been diverse, ranging from the issue of the National Reconciliation Order to the reinstatement of the Chief Justice, together with broader crises pertaining to water, power, and the economy of the country. However, the relative success of the current government to hold stead is reason enough for optimism.

\section{The $7^{\text {th }}$ NFC Award}

Hailed as a milestone for achieving fiscal federalism in the country, the NFC Award reflects a new political consensus about the necessity of transferring resource control to the provinces. The Award does that, firstly, by increasing the share of the provinces in the federal divisible pool from $47.5 \%$ to $57.5 \%$, a significant rise of $10 \%$. Furthermore, the formula for resource distribution in the Award is not solely based on population (the long-applied criterion vociferously endorsed by the Punjab province), with poverty, revenue generation and inverse population density also now being applied as distributive criteria. Moreover, outstanding issues, such as the arrears owed to Khyber Pukhtunkhwa on net hydel profits and to Baluchistan on gas development surcharge (GDS) by the center have also been agreed upon. The Award has also crucially recognized the frontline status of the Khyber Pukhtunkhwa province in the "war on terror" by apportioning an additional $1 \%$ of the total divisible pool to the frontier province.

\section{The $18^{\text {th }}$ Amendment}

The possibilities for an improved social contract in Pakistan through meaningful federal reform may have also been greatly improved by the recent unanimous approval of the $18^{\text {th }}$ Amendment in Pakistan's national legislature. The legislation, formalized after an extensive process of political consensus building, was explicitly aimed at achieving what the ruling PPP-led government calls 'participatory federalism'. An analysis of the $18^{\text {th }}$ Amendment demonstrates its significant potential-pending effective implementation-for addressing the multifaceted aspects of social exclusion in Pakistan.

Firstly, the amendments to Articles 6 and 270 of the Constitution are noteworthy in their attempt to prevent the possibility of future military takeovers, one of the principal causes of Pakistan's failed federalism. Article 6 now explicitly prohibits the judicial validation of unconstitutional military interventions while Article 270 invalidates previous endorsements of the unconstitutional actions of dictators. While this may not provide a guarantee against future military adventurism, it makes the process of the constitutional validation of military rule considerably more cumbersome, as well as improving the internal consistency of the Constitution with regards to civilian governance. 
Secondly, with the $18^{\text {th }}$ Amendment, the all-powerful executive has been weakened, with several executive powers being transferred to the premier. This strengthening of the legislative arm of government encompasses the following spheres:

- Abolition of Article 52-2(b), which crucially bars the executive from exercising the right of parliamentary dissolution, a right that has undermined the democratic process in the country on several occasions.

- Removal of presidential powers which involve the circumvention of the normal legislative process and limiting the amount of time the President may take to consider bills passed by parliament before approving them (enshrined in Article 75).

- Transfer of the power to submit matters directly to parliament for a 'yes' or 'no' vote to the Prime Minister (Article 48).

- Mandating consultation with the outgoing Prime Minister and opposition leader on presidential appointments of caretaker governments to manage the transition to a new government when parliament is dismissed (Article 224).

Thirdly, the $18^{\text {th }}$ Amendment has introduced, for the first time in Pakistan's history, education as a fundamental right of every Pakistani citizen. Article 25A makes the provision of free education to all children between the ages of five and fifteen a constitutional responsibility of the state. This is indeed a critical step in that it provides a constitutional impetus to the direction of resources towards the all-crucial area of education in an overwhelmingly young society-a step that could go a long way in removing the all important provincial, class, and ethnic disparities in vital sphere of education.

Fourthly, the Amendment removed the most glaring obstacle in the path of legislative provincial autonomy, i.e., the vast Concurrent List of legislative subjects. With the deletion of the list, provinces shall enjoy exclusive legislative powers concerning criminal law, contracts, transfer of property, labor welfare, marriage and divorce, among other significant subjects.

Fifthly, with the addition of nine new items to the Federal Legislative List II, the Amendment also enhanced the role of the Council of Common Interests (CCI) in relation to subjects of shared legislative interest between the center and provinces. The CCI has also been procedurally 
mandated to meet once every 90 days, and a secretariat for it has been established in Islamabad-steps designed to overcome its previously sporadic functioning. While such incremental steps towards provincial autonomy (the Concurrent List abolition and CCI enhancement) were crucial and also carried symbolic significance in the country, their success will hinge on (a) the acquisition by the provinces, of the skills and capacity required to exercise their new legislative and administrative authority; and (b) the success of the implementation commission in the transfer of this authority.

Importantly, Article 160 of the Constitution now specifies that future NFC agreements cannot reduce the provinces' share beyond that enumerated in the recent $7^{\text {th }}$ NFC Award. This is a significant constitutional impediment to any potential derailment of fiscal federalism in the future.

\section{Implementation of the $18^{\text {th }}$ Amendment}

As assessed above, the $18^{\text {th }}$ Amendment carries immense potential for addressing Pakistan's federalism crises, but this pivots on the question of effective implementation of the new constitutional arrangements. Overcoming the expansive legacy of centralization embedded in the systems of governance and norms of society may prove to be an immeasurably difficult task. In addition to this hurdle, the diminishing capacity of the state at the federal, provincial, and local levels is becoming increasingly apparent, making the business of decentralization ever more problematic. Institutional structures and vested interests at the federal level remain resistant to any meaningful program of decentralization, a problem which will require considerable political will to overcome.

\section{Conclusions and the Way Forward}

As discussed in this paper, federalism based on viable provincial and local autonomy must be a vital component of any reconstruction of the Pakistani state and its institutions, in order to overcome the social fractures that Pakistan is now characterized by.

Recent attempts by the political class to rectify the dynamic of provincial inequality must be supported and complemented with efforts at enhancing provincial capacities. The fact that such a unanimous political consensus for federalism currently exists across the political spectrum is an opportunity that must not be squandered. The role of civil society is also crucial at this point, as it must use this newly gained democratic space to support efforts at legislative, fiscal, and political decentralization. This role could be realized in the form of lobbying for effective implementation of 
recent reforms as well as helping to develop the capacity of the provincial states for increasing their efficacy at utilizing their newfound legislative and administrative authority.

As we move forward, it is vital that federalism be seen as a thorough realignment of powers, functions and resources at the federal, provincial, and local levels, in accordance with the needs of the sub-national unitsrather than concessionary 'privileges' and 'favors' accorded to subordinate subjects by the centralized state.

Without a basis in the Constitution, local bodies remain legally handicapped, with a high level of dependence on the provincial government. Different provinces have dealt with their local bodies in different manners. ${ }^{2}$ These have been afflicted with issues of patronage, and at times by the diversion of resources on campaigns in the context of electoral politics. Thus, the space between the provincial and local governments remains contested, and a viable solution needs to be worked out wherein the provinces provide local governments and bodies with the requisite mandate to invoke not just wider participation, but also a route into tapping grassroots potential.

In its endeavor to stimulate democracy and allow it to take roots in the local arena, the current government must build upon its legislative success to target other controversial issues such as the status of FATA, GB and the role of the Frontier Crimes Regulation-an outdated, undemocratic instrument of the British to establish authoritarian, executive command over the tribal areas. Without resolving these long-standing points of contention, broad swathes of the citizenry will be left out of the democratic sphere, leading to further alienation from a unified polity.

Keeping in mind the recent reforms which have allowed more space to provincial and local governments, the responsiveness of the federal government to these alterations becomes key to their success. The restructuring of the highest level of government becomes necessary, but this does not entail a complete transfer of power and authority to the local levels. Instead, this demands a gradual transition of authority, responsibility and legitimacy to the local levels from the center, with the federal government playing a mentorship role in the political proceedings of the local levels. Furthermore, the federal government will have to allow for the formation of demands at the local level, and itself become more reactive toward such.

\footnotetext{
${ }^{2}$ See http://www.unescap.org/huset/lgstudy/country/pakistan/pakistan.html for details.
} 
In the context of the decentralization of power, it is crucial that inter-provincial mediation bodies be activated so as to channel the emerging demands of the now autonomous provinces, which may at many times be at loggerheads with each other. This is essential for ensuring an institutionalized dialogue between the provinces and preventing acrimony amongst them. Such bodies include the Council of Common Interests, the Indus River System Authority (IRSA) and parliamentary committees.

With the rollback of the Local Government Ordinance 2001, doubts have arisen over the depleted political space for the local levels. However, given the fact that provinces have implemented the rollbacks according to their own needs and through a process of legislative debate, support to the process is legitimized. It is now to be seen whether the provincial governments have been correct in their assessment of the diminishing need of these local bodies, and whether invigorated alternatives can be introduced to stimulate political participation and engagement at the local level. 


\section{References}

AB Commentary (2003). Federalism in a Globalising World: Challenges and Responses. Economic and Political Weekly, 38 (36): 3763-3769.

Adeney, K. (2007). Federalism and Ethnic Conflict Regulation in India and Pakistan. 1st Ed. New York: Palgrave Macmillan.

Chesterman, S., Ignatieff, M., and Thakur, M. (2002). Making States Work: State Failure. United Nations, University Press.

Cohen, S.P. (2002). The Nation and the State of Pakistan. The Washington Quarterly, 25 (3): 109-122.

Constitution of the Islamic Republic of Pakistan, (2010).

Held, D. (1994). Democracy: From City-States to a Cosmopolitan Order. In The Polity Reader in Social Theory. Cambridge: Polity Press.

Goodson, L.P. (2001). Afghanistan's Endless War-State Failure, Regional Politics, and the Rise of the Taliban. Seattle and London: University of Washington Press.

Hooper, E. (2003). Review of Social Exclusion in Selected Countries in DFID Asia Region. DFID UK.

Jama1, H. (2009). Income Inequalities in Pakistan: Trends, Determinants and Impact. UNDP Pakistan.

Jones, R.W. (2001). The Prospects for State Failure in Pakistan: Ethnic, Regional, and Sectarian Fissures. Lawrence Liverore National Laboratory, 1 May.

Khan, H. (2001). Constitution and Political History of Pakistan. Karachi: Oxford University Press.

Leys, C. (1976). The 'Overdeveloped' Post Colonial State: A Re-Evaluation. Review of African Political Economy, 5: 39-48.

Mazzone, J. (2001). The Social Capital Argument for Federalism. Southern California Interdisciplinary Law Journal, 11: 27-62. 
Newberg, P.R. (1995). Judging the State-Courts and Constitutional Politics in Pakistan. 1st Ed. Cambridge: Press Syndicate of the University of Cambridge.

Rodden, J. (2005). Comparative Federalism and Decentralization: on Meaning and Measurement. Rev. Sociol. Polit, 24.

Samaddara, R.B. (2004). The Politics of Dialogue: Living Under the Geopolitical Histories of War and Peace. Aldershot, UK: Ashgate.

Singh, M.P. (2007). A Borderless Internal Federal Space? Reorganization of States in India. India Review, 6 (4): 233-250.

Sinha, A. (2004). The Changing Political Economy of Federalism in India: A Historical Institutionalist Approach. India Review, 4th ser 3 (1): 25-63.

Simeon, R. (2009). Constitutional Design and Change in Federal Systems: Issues and Questions. Publius: The Journal of Federalism, 39 (2): 241-261.

Transparency International, (2010). National Corruption Perception Survey 2010. Transparency International Pakistan.

Wasim, A. (2010). Over 12,800 Militants Caught in 2009. Dawn.com. The Dawn Media Group, $11^{\text {th }}$ January.

Watts, R.L. (1998). Federalism, Federal Political Systems, and Federations. Annual Reviews Inc. 1 (37). 
